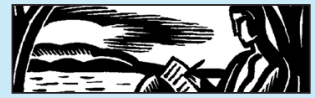

\title{
A Boy's Own Trauma: Revisiting a Photograph Recorded in a Nazi Concentration Camp First Encountered as a Child
}

\author{
Roelof Bakker
}

\section{ABSTRACT IN ENGLISH}

Photographer Roelof Bakker revisits a George Rodger photograph recorded in a Nazi concentration camp, Bakker first encountered as a child growing up in the Netherlands forty years ago. Finally developing this image, which registered in his mind yet remained unprocessed, Bakker actively engages with the photograph as a photographer, investigator and spectator, but also as a human being, integrating thought and feeling into an ethical and responsible process of analysis. Responding to critical texts by Ariella Azoulay, Ulrich Baer, Susie Linfield, Werner Sollors, and others, Bakker looks beyond the photograph as a static object, addressing the other participants in the photographic act, including the photographer's subject Sieg Maandag, and connecting the photograph to a world outside its frame, towards a future unknown at the time of exposure.

Keywords: holocaust, trauma, photograph, memory, analysis

\section{SAMENVATTING IN HET NEDERLANDS}

Fotograaf Roelof Bakker werpt een nieuwe blik op een foto genomen in een concentratiekamp in Nazi-Duitsland, die hij veertig jaar geleden als kind in Nederland voor het eerst zag. Dit beeld, dat hij in zijn geheugen had opgeslagen maar nooit echt had verwerkt, beziet hij in dit artikel door zich niet alleen als fotograaf, onderzoeker en waarnemer, maar ook als mens actief met het beeld te engageren, terwijl hij zijn gedachten en zijn gevoelens in een ethisch 
en verantwoord analytisch proces integreert. In een reactie op kritische teksten van Ariella Azoulay, Ulrich Baer, Susie Linfield, Werner Sollors en anderen beschouwt hij de foto niet als een statisch object, maar richt hij zich op de andere deelnemers aan de fotografisch handeling - inclusief het object van de fotograaf, Sieg Maandag - waarbij hij de foto verbindt met de wereld buiten het kader en een toekomst die onbekend was op het moment waarop de foto werd genomen

Trefwoorden: holocaust, trauma, fotografie, herinnering, analyse

\section{INTRODUCTION: NEGATIVE EXPOSURE}

Some photographs register in the mind, yet remain unprocessed, like the first photograph I remember seeing, at school growing up in the Netherlands in 1978, aged thirteen. This was not a photograph I looked at voluntarily. Unprepared, my eyes as yet not image-hardened, my fellow pupils and I were made to look at this photograph set in a Nazi concentration camp, as it was projected onto the screen in the classroom, part of a slideshow documenting aspects of the Holocaust.

Maybe our teacher did not realise the impact this had upon a young, undeveloped mind, or perhaps it was his intention to use photography as shock therapy, to make sure that what we were shown would never happen again. Consequently, I had difficulty sleeping, wishing what I had seen could be erased.

After having filed it away in my unconscious for forty years, thirtyfour years of which I have lived in the United Kingdom, the photograph recently came back to haunt me. What I remembered most vividly from my first encounter is the moment of exposure, like a flash going off as a photographer presses the shutter to expose the film, an experience which compares to how Walter Benjamin describes the past itself, 'like an image that flashes up at the instant of its recognisability'. ${ }^{1}$ It also recalls the shock of the unprepared reader turning the page in W.G. Sebald's The Rings of Saturn, only to be brutally confronted with the devastating image of hundreds of corpses lying scattered in a wood. ${ }^{2}$

Ulrich Baer writes that 'traumatic events, exert their troubling grip on memory and on the imagination because they were not consciously experienced at the time of their occurrence', and are only brought back into experience at a later date, 'like negatives captured on film for later developing'. ${ }^{3}$ Now that this photograph and the traumatic memory of exposure have re-entered my consciousness, I set out to respond to it in a 
vigilant, responsible and ethical way, the stylistic approach of this article's fractured analysis reflecting the nature of traumatic memory itself.

\section{'NOTHING I HAVE SEEN CUT ME AS SHARPLY, DEEPLY, INSTANTANEOUSLY'}

Susie Linfield believes that "it is hard to get our feelings "right" when it comes to [...] photographs that bring us news of the unkind things people do to each other, ${ }^{4}$ and at the time the shock of seeing left me feeling frightened, repulsed and confused, thereby not fully registering the contents of the photograph. Forty years on, I can recall harrowing details, but not its composition; I can see aspects of the "negative' ${ }^{5}$ through eyes that, at the time, were overwhelmed when faced with piles of unburied, emaciated corpses, some naked, which, in my imagination, had grown into enormous mountains of the dead, at the bottom of which a small boy walked about.

Susan Sontag too was exposed to photographs of concentration camps at an early age, accidentally seeing photographs of Bergen-Belsen and Dachau, taken after the liberation of the camps, in a bookstore, aged twelve, in July 1945: 'One's first encounter with the photographic inventory of ultimate horror is a kind of revelation, the prototypically modern revelation: a negative epiphany. [...] Nothing I have seen [...] ever cut me as sharply, deeply, instantaneously. ${ }^{6}$

No discussion took place about how we should process the shocking visuals, an experience shared with German writer W.G. Sebald, born in Bavaria in 1944, who recalled: 'When we were 17, we were confronted with a documentary film of the opening of the Belsen camp [made by the liberators, the British Army]. There it was, and we somehow had to get our minds around it, which of course we didn't. It was in the afternoon, with a football match afterwards. So it took years to find out what had happened. ${ }^{7}$

Roland Barthes remembered being shocked by a photograph of a slave market when he was a boy; as it was a photograph, it gave him the 'certainty that such a thing had existed' ${ }^{8}$ Linfield argues that photographs are particularly effective at making us see cruelty, because they possess 'a literalness and an irrefutability that neither literature nor painting can claim'. ${ }^{9}$

Seeing the horrors in a photograph as a secondary witness, as a postmemorial experience, was also shocking in the absolute certainty that what I saw was real and incontrovertible, that such a place as BergenBelsen had truly existed. Marianne Hirsch defines post-memory as the relationship that the 'generation-after bears to the [...] trauma of those 
who came before-to experiences they "remember" only by means of the stories, images, and behaviours among which they grew up', experiences transmitted so deeply, they 'seem to constitute memories in their own right'. ${ }^{10}$

In my case, the photograph's horrific revelations stayed with me as a disturbing, unresolved traumatic experience, yet the shock of seeing the photograph also delivered a traumatic memory that is entirely my own.

\section{ENTER THE KEYWORDS 'BODIES', 'CONCENTRATION CAMP', 'BOY' AND 'BERGEN-BELSEN'}

When I search for the photograph online, entering the keywords, 'bodies', 'concentration camp', 'boy' and 'Bergen-Belsen', I wonder why I assume the photograph was taken at Bergen-Belsen. When I retrieve it, I realise I know it well; I have seen it many times over the years, but have never really taken the time to look at it, nor made the connection with the photograph I had filed away in my memory.

Displayed at low resolution on my monitor, the photograph does not depict the enormous mountains of the dead I imagined I remembered, and for one moment I feel inappropriately disappointed, before questioning how truthful the memory of seeing a photograph really is.

The photograph is by British war photographer George Rodger, who entered Bergen-Belsen concentration camp on 20 April 1945, five days after it had been liberated by British troops. ${ }^{11}$ I do not remember that this photograph was taken after the liberation of Bergen-Belsen. The photograph does not express the joy and excitement I saw as a secondary witness in photographs of the 1945 liberation of the occupied Netherlands. It shows that in Bergen-Belsen, even after the liberation of the camp, the horror continued.

To study the photograph in detail, I retrieve a copy of George Rodger's monograph, which includes a large reproduction of the photograph made from its original negative identical to Figure 1 below, sourced from Getty Images. ${ }^{12}$

As I slow-view it, I am horrified again at the sight of emaciated corpses, some naked and disfigured, casually disposed of, yet laid out neatly on an embankment to the side of a road. The clearly visible faces of two female corpses to the bottom right of the photograph are particularly haunting.

When Linfield quotes Benjamin, 'There is no document of civilization, which is not at the same time a document of barbarism', she subsequently points out that with photography the opposite is also true. ${ }^{13}$ In this document of barbarism, civilization appears in the shape of a smartly dressed boy, seven or eight years old, three or so years younger than my parents at 


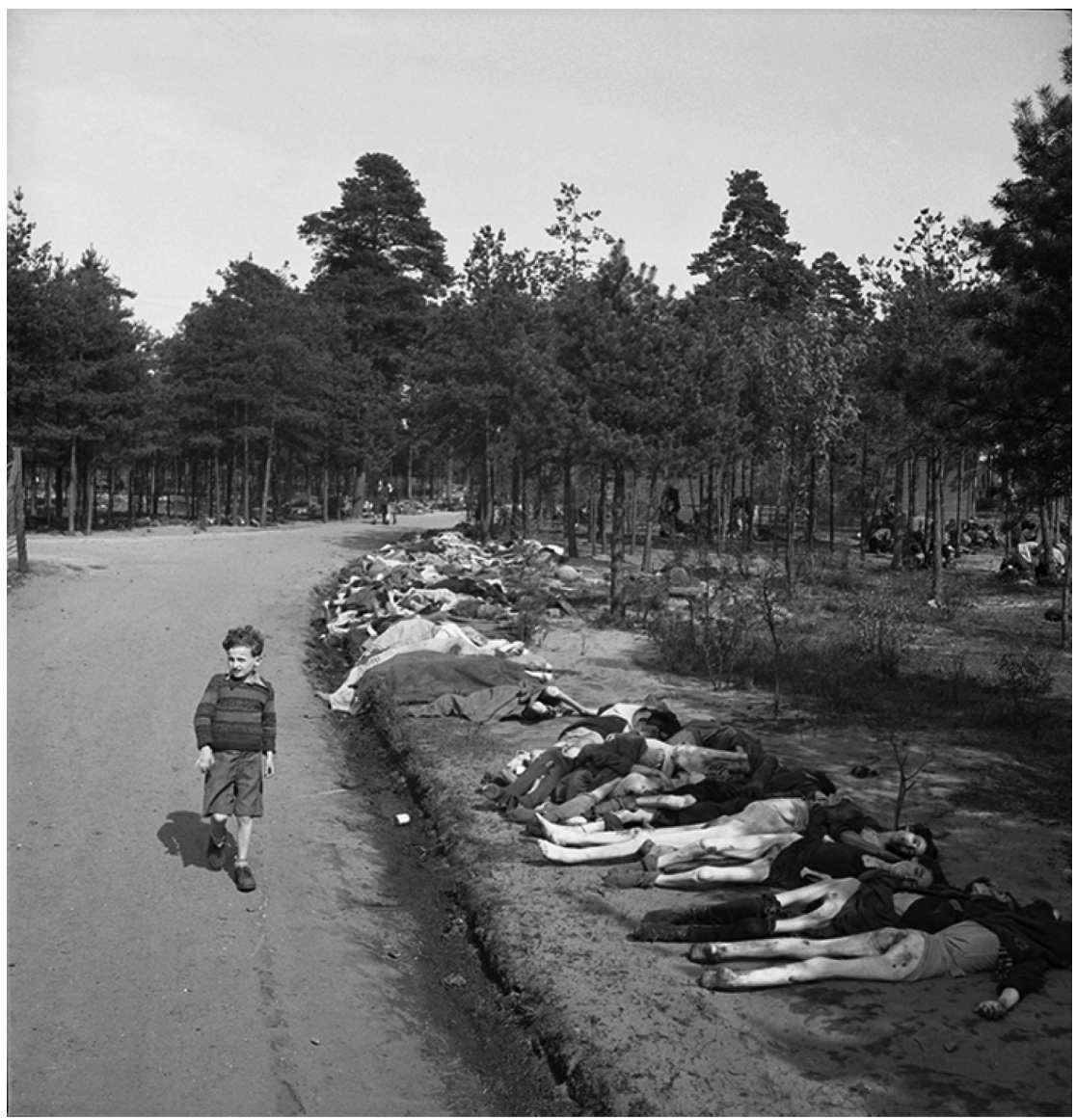

Fig. 1: Rodger, 1945. 'Young boy dressed in shorts walks along a dirt road lined with the corpses of hundreds of prisoners who died at the Bergen-Belsen extermination camp, near the towns of Bergen and Celle, Germany, April 20, 1945.' The Life Picture Collection/ Getty Images (online, reference 622949528). https://www.gettyimages.co.uk/ license/622949528. Student licence purchased 9 July 2018. [photograph]

the time, who, when the photograph was taken, were children growing up in Friesland, in the north of the Netherlands.

The boy, whose physical appearance I have no recollection of, walks on his own down a road, past hundreds of corpses; he does not look at them, his face is directed towards the photographer. He is the main focus in the photograph and offers a way in to the scene as well as a way out: looking at him avoids being confronted with the corpses by the roadside. 
Barthes writes that a detail of a photograph can totally overwhelm the entirety of its reading: 'a "detail" attracts me. I feel that its mere presence changes my reading, that I am looking at a new photograph, marked in my eyes with a higher value. ${ }^{14}$ He calls this detail the punctum-something in a photograph that triggers an unexpected reaction, that provokes 'a tiny shock'. ${ }^{15}$

The boy's smart outfit seems entirely out of place, and it is this aspect that overwhelms the photograph for me, shocks me, because it confronts me with the kind of boy I once was; I can identify with him, this boy in shorts, going for a walk on a spring day, the sun in his face. His attire, however, contrasts bluntly with the landscape of horror around him, his presence confusing me, frightening me.

Who is this well-dressed boy walking about on his own in a concentration camp? Why is he there? Where is his mother? His father? What happened to him afterwards? Did he live? Was he traumatised? Who photographed him and why? Was the photographer traumatised?

The photograph evokes many questions, questions the photograph itself is unable to answer. What I witness cannot be understood by the act of looking alone.

\section{'THE BEGINNING OF A DIALOGUE, THE START OF AN INVESTIGATION'}

Both Barthes and Sontag approach photographs as static objects, with Barthes observing a photograph as 'crammed: no room, nothing can be added to it', ${ }^{16}$ while Sontag believes harrowing photographs 'do not inevitably lose their power to shock. But they are not much help if the task is to understand'. ${ }^{17}$ Cornelia Brink observes that photographs taken after the liberation of the camps are usually taken at face value and 'make a moral claim to be accepted without questioning'. ${ }^{18}$

Should photographs of trauma not require a more open-minded and responsible, broader analysis instead of being taken as static, fixed records of a moment in time?

Baer suggests the spectator assumes a responsibility "not merely to view the evidence offered [...] but to read, to interpret, to tear open what they think they know, and to respond', ${ }^{19}$ while Linfield argues for thought and emotion to be part of the analysis. A photograph's ambiguities can be a starting point of discovery by connecting it to a world outside the photograph's frame, so they become 'part of a process-the beginning of a dialogue, the start of an investigation'. ${ }^{20}$

Ariella Azoulay argues that to analyse a photograph, all participants in the photographic act need to be addressed: camera, photographer, 
photographed environment, object person, and spectator. ${ }^{21}$ She proposes an unwritten, civil contract of photography, in which each participant of the photographic act has a civic duty towards the other participants. Like Baer and Linfield, Azoulay argues the spectator has a duty to respond actively and ethically to a photographic event, and reconstructing this event requires more than just identifying what the photograph shows. ${ }^{22}$ For Azoulay, still photographs should be interpreted as moving pictures: they need to be watched, as by watching a photograph 'dimensions of time and movement' are introduced into 'the process of looking. ${ }^{23}$

To develop the Rodger photograph, I need to respond to the image responsibly and ethically with thought, emotion and knowledge, while also looking beyond the boundaries of composition and of time, addressing the actions of all participants in the photographic act.

\section{A REMARKABLY WELL-DRESSED BOY}

I begin my investigation by studying the boy up close. My initial response is to read him as a German: the contrast between him, a remarkably welldressed boy, and the barbaric scene showing the discarded dead, invites me to speculate in this way. Is he a local child made to face the horrors committed in his name, after the camp's liberation? If he is German, even as a child, can I allow myself to feel any empathy for him?

The devastating setting of the photograph makes it entirely inappropriate to make assumptions about the child portrayed without supplying evidence. The photograph is not a game after all. This is a child, and are children not supposed to be innocent? The photograph conveys one boy's life experience in a landscape of trauma. Surely, as a human being, my only option is to empathise?

Hirsch explains that because of their undeveloped awareness of identity, children are easily open to projection and identification. ${ }^{24}$ In-depth research conducted by Werner Sollors about the boy in the photograph shows I am not alone in my assumption, as the boy has been identified many times before as German, as a representative of Nazi Germany, 'for which there is, after all, no evidence in the picture itself, only in the contexts in which it has been viewed and in the captions it has been given'. ${ }^{25}$

Sollors states that this photograph 'became an allegory, not just of the contrast between life and death, but also of the gulf between ordinary, relatively well-off, well-clad, and innocent-seeming Germans and the Nazis' starved, tortured, and slaughtered victims [...] seen this way, the seemingly healthy boy in the picture appeared to some viewers not as someone worthy of sympathy but as an uncaring witness to the bloody results of a reign of terror'. ${ }^{26}$ 
As Sollors points out, as recently as 2005 the photograph was included in a study of post-war Europe, in which the boy is captioned as a German without a conscience. ${ }^{27}$ The caption reads: 'Shortly after Germany's defeat in 1945, a child walks past the corpses of hundreds of former inmates of Bergen-Belsen concentration camp, laid out along a country road. Like most adult Germans in the post-war years, he averts his gaze.'28

On closer inspection, the boy may appear well-dressed, but his clothes are too big for his frame and I fail to register him as healthy-seeming, with his gaunt and drawn face, unkempt hair and bony legs.

There is no evidence in the photograph that the boy is German. What I require are facts, answers to questions.

\section{TURN TO THE PHOTOGRAPH AND ADDRESS THE BOY BY HIS NAME}

Barthes, writing in 1980, refers to a 1931 photograph by André Kertész of a Paris schoolboy, exclaiming excitedly, "it is possible that Ernest is still alive today. But where? How? What a novel!' ${ }^{29}$ What about the boy in the Rodger photograph? Did he have a life after the camp? If so, how and where?

In previously un-shown footage in 'De film die nooit afkwam' [the film that was never completed], a 2017 reworking of an unfinished 1978 Dutch documentary about the boy in the photograph, I learn that the boy survived and lived into this century (he died in 2013), his name Sieg Maandag, a Dutch Jew from Amsterdam. ${ }^{30}$ I am amazed to discover that the boy is not German but someone from my country, who had been sent abroad to die.

Sollors' 2014 research about the photograph did not include elements from this source, although he does mention the existence of footage recorded in $1978 .{ }^{31}$ The film offers additional insights into the experiences and memories of both the boy and the photographer, recorded thirty-three years after the end of the war.

I turn to the photograph and address the boy by his name: Sieg Maandag. Saying his name out loud makes him real; he is no longer just a subject in a photograph, open to speculation and projection, but someone I share a language with, a nationality, a country of birth.

In the 1978 footage, Maandag is forty-years old, living in Amsterdam, married to Karen. Their first child Sarah was born that year; a son, Simon, in $1981 .{ }^{32}$ Maandag preferred not to elaborate on his time at BergenBelsen, and, after the 1978 documentary project collapsed, his name did not become public until the early 1990s. Fifty years after the war, in a 1995 interview for Dutch newspaper De Telegraaf, he wrote a letter to himself, 
permitting himself to talk about his camp experiences. Part of the letter is reprinted at the beginning of the article. ${ }^{33}$

'You will never hear a word about the war from me. Me, who is already traumatised, who lives in a world, in which wars are the order of the day, where people are tortured and children are abused-a world full of the traumatised. [...] Only when I am asked specifically, I will talk about it. ${ }^{34}$

From the newspaper interview I learn Maandag has received psychiatric help throughout his life to assist him in coming to terms with his traumatic past. He is quoted saying, 'There were moments when I considered jumping out of a window. What was that all about? No, the traumatised need help. ${ }^{35}$

One way he dealt with his traumatic past was to become a practising artist, using painting as a method of expression, as a means of healing. 'Picasso said it before, "Painting is therapy". 36

Learning Maandag's name and finding out about his traumatic life beyond the camp, in the Netherlands, makes the photograph personal and real.

\section{'I WAS JUST STANDING IN THE ROAD AND HE CAME WALKING ALONG'}

British photographer George Rodger, employed as a war correspondent by American magazine Life, entered Bergen-Belsen on 20 April 1945. He had never seen anything as harrowing, as he recorded hundreds of corpses, as well as the starving and dying lying around the camp. ${ }^{37}$

Barthes reminds us of the importance of chance encounters. A photograph not only happens because a photographer takes it, but also because he is at a specific location at a certain time: "his second sight" does not consist in seeing but in being there. ${ }^{.98}$ As Rodger explored the camp with his camera, he stumbled upon a small boy: 'It's one of the pictures I remember-very very well and I often wonder [...] this poor little boy here coming along and I was just standing in the road and he came walking along. ${ }^{, 39}$

Directing his eyes at Rodger's lens, Maandag faces the bright midday sunshine, his eyes squinting, his right hand slightly blurred, suggesting Rodger may have used a small aperture to obtain maximum sharpness, or perhaps Maandag is rushing to get away from the smell of the corpses deposited on the embankment by female camp guards. ${ }^{40}$ In an interview Maandag said: 'Death was everywhere. The diseased were thrown on a heap or in ditches. The stench was awful. ${ }^{41}$

As Maandag's mouth is open, it suggests the possibility of a conversation, however brief. Azoulay points out that a photograph is evidence of the social relations which made it possible, therefore "what was there is 
never only what is visible in the photograph, but is also contained in the very photographic situation, in which photographer and photographed interact around a camera', ${ }^{4}$

Maandag's expression is open to interpretation. The first word that comes to mind to describe it is traumatised, but he also looks shy and vulnerable, a vulnerability juxtaposed to the cruelty around him, and, as Linfield emphasises, 'vulnerability is something every human being shares; the cruelty is something that shatters our very sense of what it means to be human'. ${ }^{4}$

Azoulay argues that the photographer exploits 'the photographed individual's vulnerability'. ${ }^{44}$ Exploitation is clearly evident here, as Rodger, whether intentionally or not, brutally exposes the boy's vulnerability, in the process robbing him of 'his intimacy'. ${ }^{45}$

Perhaps Maandag asked Rodger not to photograph him; after all, who would want their picture taken in such a harrowing place? Or is he frightened, submitting to the demands of an adult stranger, a professional photographer whose language he does not speak, a man who might hurt him? Maandag recalls how fear had become part of his everyday life at Bergen-Belsen and beyond, 'I kept that fear with me for a long time'. ${ }^{46}$

This photograph is a unique record of a brief moment of communication between strangers, a photographer who seized a photographic opportunity and a traumatised boy. At the time neither could have predicted the photograph's future trajectory.

\section{'NEW DEMANDS ARE MADE ON REALITY IN THE ERA OF CAMERAS'}

The photograph was first published, without credit, in a cropped version in American picture magazine Life on 7 May 1945, as a full page image opening a six-page photo essay portraying atrocities committed by the Nazis in German concentration camps including Bergen-Belsen and Buchenwald. ${ }^{47}$ The previous page, an editorial piece about the end of the war in Europe, is illustrated by a full-page photograph documenting the euphoric embrace of an American and a Russian lieutenant, captioned: 'At the Elbe River a U.S. and a Russian lieutenant meet to link the American and the Soviet armies. ${ }^{48}$

This contrasts with the caption of the Rodger photograph overleaf, which reveals nothing about the identity of the boy or of the corpses, as it matter-of-factly states: 'A small boy strolls down a road lined with dead bodies near camp at Belsen. ${ }^{\text {'9 }}$

The brief article accompanying the photo essay, entitled 'Atrocities,' mentions 'political prisoners and slave laborers, living and dead', but the 
text does not once refer to Jew, Jewish or genocide. ${ }^{50}$ Even in the documentary, 'De film die nooit afkwam', I do not hear the word Jew once. ${ }^{51}$

As Sollors points out, in the version in Life (Figure 2) the faces of the corpses to the right have been cropped from the square negative and the photograph has also been retouched. ${ }^{52}$ I observe the nakedness of four corpses to the bottom right of the photograph is removed by extending clothing, and one victim's body is covered by a blanket, painted over the image ${ }^{53}$ This raises the question whether other Holocaust photographs were altered at the time. As Sontag points out, "new demands are made on reality in the era of cameras' ${ }^{54}$ However, new demands are also made by magazine editors and as Sollors suggests,

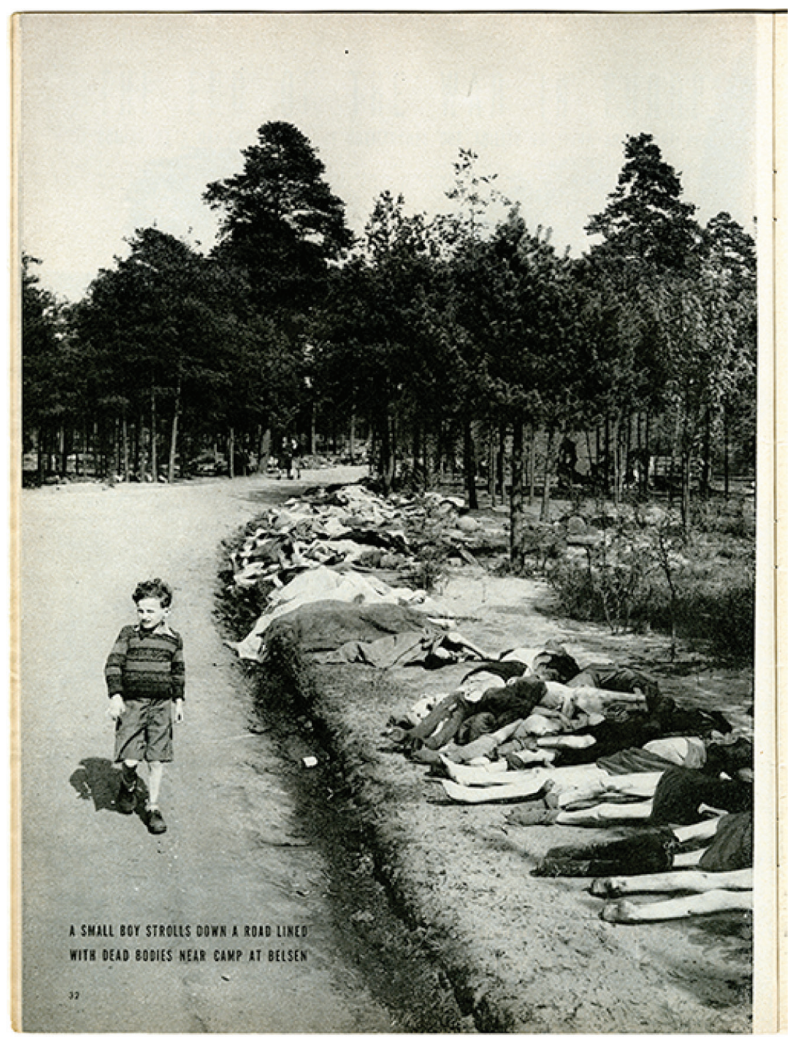

Fig. 2: Rodger, 1945. 'A small boy strolls down a road lined with dead bodies near camp at Belsen'. From: Life, 7 May 1945. 18:19. New York: Time \& Life, 1945, 32. (private collection). [scan of magazine page] 
'the exposed nakedness of some of the dead bodies in the foreground [...] must have seemed too scandalous for publication for the editors of a family magazine. ${ }^{55}$

I cannot recall which version of the photograph I witnessed as a boy, particularly as a third version is available at Getty, which was included in the previously mentioned Postwar: A History of Europe Since 1945. ${ }^{56}$ Here, three corpses to the front of the photograph have been retouched differently from the version that appeared in Life in $1945 .{ }^{57}$ However, I believe whatever is done to this photograph, mechanically or textually, it is impossible to conceal its horrors.

\section{'AND THINK ONLY OF A NICE PHOTOGRAPHIC COMPOSITION'}

Rodger may have set out to compose his photograph, but he may not have been aware of the details recorded in the background. As a document to study, the uncropped version conveys much more than one living boy and hundreds of corpses. Maandag is not the only living person in the photograph, as about fifty meters behind him, two young women walk together, like Maandag, towards the sun.

The camera always sees 'more than the photographer', Linfield concludes after analysing photographs taken inside the Warsaw ghetto by Nazi photographer Heinrich Jöst ${ }^{58}$ and Baer argues that 'confronting photographs of trauma requires us to decode the ways in which the camera programs the shots'. ${ }^{59}$

Additional corpses lie in the pinewood forest at the other side of the road, the sun highlighting their presence, possibly the same location as the photograph of corpses included in the The Rings of Saturn, also taken by Rodger on 20 April $1945 .{ }^{60}$ At the top right, in front of a wooden barracks, I detect additional life: survivors standing, leaning, squatting or lying down. Bergen-Belsen was an overcrowded camp where prisoners were cruelly left to starve to death. Even after liberation 13,000 people died ${ }^{61}$

In his eyewitness report recorded at the camp, Rodger writes about the conditions around him. His words reveal the darker aspects of the camp, outlining the desperation of barely alive survivors and their search for food in revelations that I found to be devastating: 'The living lay side by side with the dead, their shrivelled limbs and sunken features making them almost indistinguishable [...] Naked bodies with gaping wounds in their backs and chests showed where those who still had the strength to use a knife had cut out the kidneys, livers and hearts of their fellow men and eaten them that they might live themselves. ${ }^{62}$

The photograph may be a carefully-considered composition; however, Sontag suggests composition devalues the atrocity photograph, 'For the 
photography of atrocity, people want the weight of witnessing without the taint of artistry' ${ }^{6}{ }^{63}$ After analysing this photograph, I can only disagree; after all, the details in a well-composed photograph like this can reveal much more than its author intended.

For Rodger himself, photographing Bergen-Belsen was traumatic. His time there marked the end of his career as a war photographer: 'When I discovered I could look at the horror of Belsen [...] and think only of a nice photographic composition, I knew something had happened to me and it had to stop. I felt I was like the people running the camp-it didn't mean a thing. ${ }^{.64}$

Carole Naggar emphasises, 'He was so traumatised by Belsen that for the next forty-five years he could not bear to look at the pictures he had made there and wished he could erase them. ${ }^{65}$ However, in the 1978 footage of the unfinished Dutch documentary, Rodger holds a copy of Life, pointing at the photograph whilst being interviewed about it, this particular image very much an important part of his existence, even if traumatic, not one he could not face. ${ }^{66}$

\section{NEVER EVEN CONSIDERED WHO TOOK THIS PHOTOGRAPH AND WHY IT WAS TAKEN}

Linfield emphasises the importance of knowing who the photographer is, who is being photographed and why and for what purpose a photograph is taken, stating "many factors [...] determine the kind of photograph that he will take'. ${ }^{67}$ She points out that most viewers are unaware or unable to 'distinguish their source or the context of their production. Indeed, in the vast archive of photographic images that have come down to us from the Holocaust, this information is often difficult to detect' ${ }^{68}$

What if the Rodger photograph had been taken before the liberation of the camp, by a perpetrator, a German photographer? The reading of the photograph would be a completely different one, the photograph's objective part of the Nazi propaganda machine.

Linfield invites us to consider one of the most iconic images of the Holocaust, also a photograph of a small dark-haired Jewish boy in shorts (Figure 3), 'his hands raised in the air, as he is rounded up for deportation' ${ }^{69}$ Not only is a gun pointed at the boy by a soldier behind him, a perpetrator's camera lens is also directed at the boy, the camera playing an active part in the terror machine.

The picture was taken by an unknown photographer employed by the Nazis in May 1943, as part of the photography-laden Stroop Report, "which was written for the Nazi leadership and which certified-indeed boastedthat the Warsaw Ghetto's Jews had been successfully "terminated". ${ }^{70}$ 


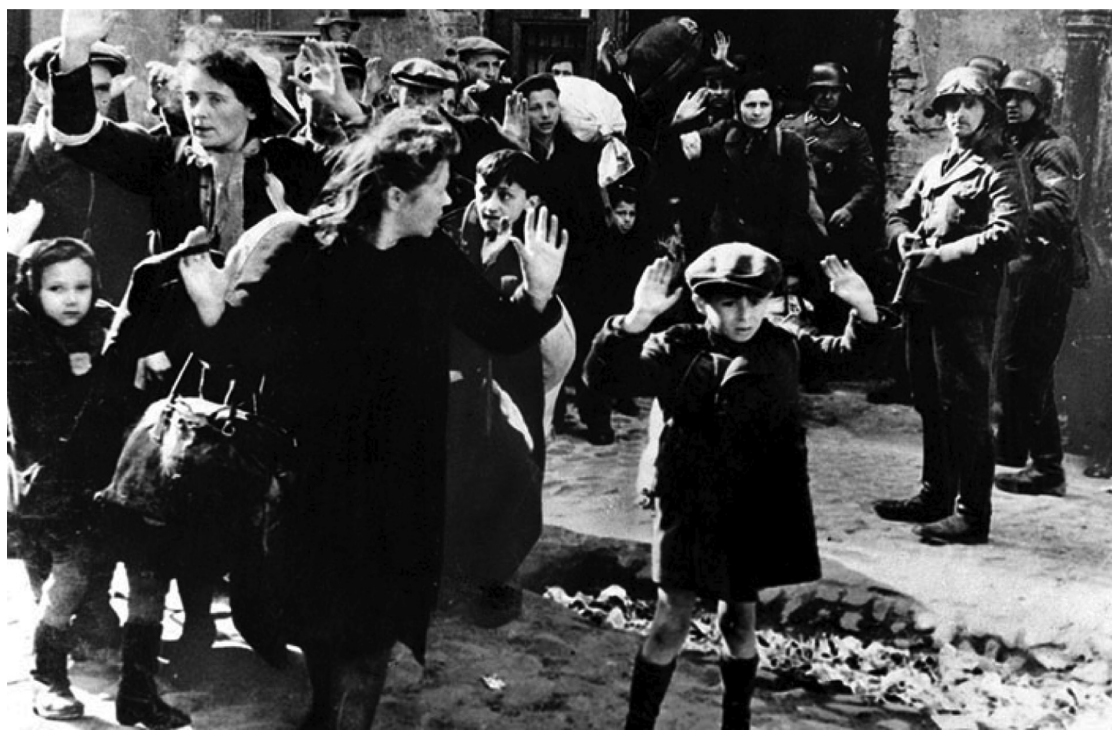

Fig. 3: Anon, 1943. 'Nazis arresting Jews in Warsaw ghetto.' Hulton-Deutsch Collection/ CORBIS/Corbis via Getty Images (online, reference 613463274). https://www. gettyimages.co.uk/license/613463274. [photograph]

I have never previously considered, or questioned, who took this photograph and why it was taken. History and time have changed its intended purpose and I agree with Linfield, who states, 'to me, this photograph protests the boy's helplessness and terror rather than praises the killers' admirable efficiency' ${ }^{71}$

The Rodger photograph also shows a helpless dark-haired boy in a landscape of terror, recorded after Germany's surrender, by an Allied photographer. Unlike the boy in the Warsaw ghetto photograph, Maandag was safe in the company of his photographer and escaped brutal murder as one of only 5,000 Dutch Jews of the 107,000 deported who survived the war. 75 percent of Dutch Jews were murdered, the highest percentage of Jewish victims in Western Europe. ${ }^{72}$

\section{'WHAT HAS STAYED WITH ME OF THE CAMP IS [...] THE LONELINESS'}

Sieg Maandag, his father Isaac, a diamond merchant, his mother Keetje, and his younger sister Hendrika were rounded up for deportation in 1943 
and spent a number of days at the overcrowded Hollandsche Schouwburg in Amsterdam, a theatre used as a registration and assembly point for Jews to be deported ${ }^{73}$ From there they were sent by train to Westerbork, a Dutch transit camp, before being deported to Bergen-Belsen in Germany in 1943, where they were due to be part of a diamond cutters unit to be set up in the camp, which however never came to fruition. ${ }^{74}$ They stayed in a section called the star camp, where the Jewish star had to be worn on their civilian clothes. ${ }^{75}$

His father and mother were sent away from Bergen-Belsen in December 1944, leaving Maandag and his sister behind. ${ }^{76}$ In the 1978 footage, Maandag spoke of the devastating loneliness he experienced at the camp:

'What has stayed with me of the camp is [...] the loneliness. I remember waking up one night, it was as if I was wearing a suffocating cloak of loneliness. I was feeling indescribably lonely. [...] that particular moment, symbolised the entire camp experience [...] of course there were the corpses and all the other things I remember, but that one feeling [...] you could almost call it shocking, and that was the longing for my mother. And to this day, I remember that one feeling. ${ }^{77}$

This quote evokes another reading of the photograph, as a portrait of the loneliness of trauma, of a boy desperately missing his mother. Rodger emphasises this loneliness by framing Maandag as the only living human being to the front of the frame, against a road which is wide and daunting, the trees in the background hovering over him, the forest dense and menacing. Everyone in close proximity is dead, the people who are alive, including the two women walking and the people sitting by the barracks, are far behind him, out of reach.

Personal testimonies open up alternative interpretations of a photograph, helping reveal the reasoning behind the subject's actions and exposing his deepest feelings.

\section{A HUMAN BEING, A PERSON, UNBRANDED, NOT MARKED OUT FOR EXTERMINATION}

A remarkable aspect of the photograph is that Maandag has disposed of his old clothes, allegedly after he discovered a closet in the SS section of the camp, which contained, as he said, 'shelves of clothes of people who had died. Germans who were killed. Children'. ${ }^{78}$

This is contradicted by a caption accompanying this photograph in a comprehensive 2019 photography exhibition documenting the persecution of Dutch Jews, 'De Jodenvervolging in foto's, Nederland, 1940-1945' [The persecution of Jews in photographs, Netherlands 1940-1945] at the National Holocaust Museum in Amsterdam. The caption headed 
'Liberation' states Maandag 'received new clothes from the liberators', ${ }^{79}$ words undermining his action. In the 1995 interview with Thomas Rahe cited above and quoted in Sollors, Maandag however, clearly states his new clothes are not a gift from Life magazine:

Interviewer: 'The explanation for the fact you are quite well dressed for the picture is that after liberation you got new clothes from the magazine.'

Sieg Maandag: 'I don't know what you mean by the magazine. Die Magazine! [German for store rooms]. No there was nothing. That was from the piles. There were piles of clothes. ${ }^{90}$

Until the camp was liberated, it is likely he was wearing the Jewish star as required by the camp authorities, as a 'star camp' prisoner. ${ }^{81}$ But through the act of changing clothes, he has normalised himself, reclaiming himself as a human being, a person, unbranded, not marked out for extermination.

Two weeks after the photograph was taken it appeared in Life, the photograph showing the world that Maandag was ready to leave the camp. An uncle of Maandag's who had emigrated to New York discovered his nephew's photograph in the magazine. He sent copies to the Diamond Exchange in Amsterdam where Maandag's father had worked. The magazine was subsequently given to Maandag's mother, who had survived the war and was back in Amsterdam looking for news about her children. Here was the proof that her son might be alive and soon Maandag and his sister were reunited with their mother, ${ }^{82}$ Maandag's father having died at Bergen-Belsen. ${ }^{83}$

By appearing in an American magazine, this harrowing photograph brought immeasurable joy to a Dutch Jewish mother, its publication helping reunite her family.

\section{A FUTURE THAT FROM WITHIN THE IMAGE IS STILL RADICALLY UNDECIDED AT THE TIME OF EXPOSURE}

Photographing a young boy in such a harrowing place left a deep mark on Rodger. In footage from the unfinished 1978 film, Rodger is visibly moved when he learns the name of the boy and that he had survived the war: 'Every time I see this picture, I wonder [...] whatever happened to this little fellow [...] I didn't even know his name. What's his name? [...] Sieg Maandag. [...] It would be terrific if I could see him again after all these years. I wonder if he remembers the picture being taken? I shouldn't think so, because he can't be more than, what? Seven or eight years old [...] He remembers it? And he survived this? Good Lord.' ${ }^{84}$

The original idea behind the 1978 documentary, which had Life's Picture as its working title, was to reunite Rodger and Maandag and to record this 
meeting. However, Rodger disassociated himself from the project in a telegram sent to the Dutch production company in 1978, his words revealing deep emotional investment in the photograph: 'I felt in this case he [Bromet, the director] lacked the sensitivity and human understanding which alone would allow me to feel secure and at ease in the production of a film which concerns my deepest personal emotions. ${ }^{85}$

The failure of the film project did not stop Rodger and Maandag meeting up for a reunion in Amsterdam in 1981, the reunion part of their healing process, as much as researching this photograph is part of mine. The photograph played an active part in both their lives, the strength of the moment and its circumstances instigating a bond between them of witnessing, of knowing, of trauma. A touching photograph, in which both men study the image in Life magazine, is included in Rodger's 1994 monograph, ${ }^{86}$ with a different version included in Sollors' text. ${ }^{87}$

It is a powerful thought that they met again because of a photograph, which opened 'onto a future, that from within the image is still radically undecided at the moment of exposure. ${ }^{98}$

\section{CAPTIONS HAVE LET THE PHOTOGRAPH DOWN FROM ITS FIRST PUBLICATION}

Barthes, writing about the connotations between the [press] photograph and the text that accompanies photographs in journalism, points out that in every context a photograph is used the text can add one or multiple meanings onto a photograph. ${ }^{89}$ As Rodger knew the name of the boy since 1978, it is disappointing to find the following caption in Rodger's 1994 monograph: '1945, Belsen, a Dutch Jewish boy walks through the camp. ${ }^{90}$

Captions have let the photograph down from its first publication in Life. ${ }^{91}$ The caption here is misleading, as it does not state the photograph was taken after the liberation of Bergen-Belsen. Maandag is listed as a 'Dutch Jewish boy', a subject made object, like before, when he wore a yellow star as a prisoner in the 'star camp'. ${ }^{92}$

It seems odd to arrive at this stage of my research to find that Maandag has become nameless again (the Getty Images caption also disappoints, listing him as a 'young boy'; see Figure 1). It has been important to address him by his name, Sieg Maandag or Maandag, once I gained this knowledge, thereby validating his traumatic existence in BergenBelsen and beyond.

Sieg Maandag, as the photographed individual with a name, 'is abandoned' by the photographer and his publisher, ${ }^{93}$ after all he has no control 
over his image and how it is presented. However, portraits included in the same publication of the camp commandant at Bergen-Belsen and five female camp superintendents are all name-captioned..$^{94}$ It confirms Sontag's observation that 'to grant only the famous', or here the notorious, 'their names demotes the rest to representative instances of their occupations, their ethnicities, their plights'. ${ }^{95}$

The Telegraaf newspaper interview in 1995 rectified this, as it is the first time the photograph is name-captioned. ${ }^{96}$ As Sollors states, 'Once given a name, once identified, the child portrayed in Rodger's photograph can no longer appear as a mere allegory' ${ }^{97}$ Sollors' 2014 research about the boy in the photograph made Maandag's name and story more widely public, paving the way for researchers and historians alike to name-caption the photograph correctly. ${ }^{98}$

Included in the 2019 exhibition De Jodenvervolging in foto's, Nederland 1940-1945 at the Nationaal Holocaust Museum in Amsterdam, ${ }^{99}$ Maandag's home town, the photograph is receiving wider exposure. An article in Dutch newspaper Het Parool in May 2019 drew attention to the fact that the photograph has been retouched. The version included is the same one that was included in Postwar: A History of Europe Since 1945, ${ }^{100}$ available from Getty Images. ${ }^{101}$ Sollors, who first highlighted the existence of three versions, is quoted saying in a telephone interview, 'I think people should see the original photograph. That's the reality that Rodger recorded'. ${ }^{102}$

I assumed this retouched version was chosen to lessen its shock to a younger audience, but it appears the curators of the exhibition had never seen the original of what is possibly the most harrowing photograph in the exhibition. From personal experience and from carrying out this research, I believe whatever version is shown to children needs contextualisation and discussion and therefore I have reservations about the photograph being included. ${ }^{103}$

The exhibition caption includes both Maandag's name and age, although, as stated before, it incorrectly implies he received clothes from the liberators. ${ }^{104}$ In the accompanying publication, the date of the photograph is also listed incorrectly as 17 April $1945 .{ }^{105}$

The caption I would propose, one which does not confuse and is factually correct, would read as follows:

Bergen-Belsen, Germany, 20 April 1945. Sieg Maandag, 7, a Jewish Dutch boy, a victim and survivor of Bergen-Belsen concentration camp, walks through the camp on a road lined with corpses, five days after liberation, wearing clothes he retrieved from a Nazi store room soon after the camp was liberated. Photograph by British war photographer George Rodger for Life magazine. 


\section{BRINGING THE HOLOGAUST HOME}

Researching this photograph made me aware how little knowledge I have of the persecution of Dutch Jews in the Netherlands during the Nazi occupation and how the Dutch population and government in exile responded to this.

Van Berkel points out that the current Dutch Prime Minister, Mark Rutte, did not know of the De Hollandsche Schouwburg when questioned by a journalist in 2012. Van Berkel asks, 'If the prime minister is ignorant of the matter, what can we expect of the general public to know? ${ }^{106}$

I only learnt of De Hollandsche Schouwburg in 2018 when I was researching my Masters dissertation, on which this article is based. The 1995 interview with Maandag for De Telegraaf mentioned his family were held there before being deported to Westerbork. ${ }^{107}$ I discovered the Schouwburg has been a Holocaust monument since 1958 with a memorial wall bearing the 6,700 family names of the 104,000 Dutch Jewish victims of the Second World War. ${ }^{108,109}$

A new generation is becoming aware of the Holocaust from a Dutch perspective; on both times I visited De Hollandsche Schouwburg, several groups of school children were visiting. There were also children at the 2019 exhibition 'De Jodenvervolging in foto's, Nederland 1940-1945'-the first major exhibition in which the visual history of the persecution of the Jews in the Netherlands during the Second World War is shown, seventyfour years after the end of the Second World War. ${ }^{110}$

It was the first time I saw an in-depth exhibition bringing the Holocaust home, with captioned photographs showing how Jewish lives were marginalised and cut off from the rest of the population in a short period of time before being deported. I was mostly unaware of this history, told in-depth in the meticulously researched Veel Valse Hoop. De Jodenvervolging in 1940-1945 Nederland [Many False Hopes: The Persecution of Jews in the Netherlands, 1940-1945], by German historian Katja Happe. ${ }^{111}$

\section{CONCLUSION}

A photograph I was made to see as a boy growing up in the Netherlands forty years ago has haunted me ever since I was exposed to it. When I started my research, I had foggy and disturbing memories of its content and knew nothing about the boy in the picture nor his photographer. What I remembered most vividly were corpses lying by the side of a road, some partly naked. 
I asked many questions and found answers beyond the image itself, my investigation directed by critical thinking and research by Azoulay, Baer, Barthes, Hirst, Sollors and Sontag amongst others. The processes employed confirmed that a photographer is 'responsible for the ethics of showing', ${ }^{112}$ but also that the spectator assumes an active responsibility, enabling photographs to 'open up to a future that is not known, [...] which might yet be changed'. ${ }^{113}$

Photographs of trauma require contextualisation, something my teacher in the Netherlands did not offer his students. He simply exposed us children to it, alongside other photographs documenting aspects of the Holocaust. I continued my history lesson many years later, researching and writing this article, learning much about Rodger and Maandag. The stories of human suffering of the corpses will remain forever unheard, including, to my knowledge, those of the two women whose faces are clearly visible in the front of the frame. They were human beings once with families, and hopes for the future, not pieces of junk to be left by the side of a road. Linfield states that such records of suffering have a purpose as they function as 'documents of protest: they show us what happens when we unmake the world'. ${ }^{114}$

As a spectator, assuming an active responsibility towards a photograph requires dedication and time, but as my research highlights, there is much to gain from what is a slow yet rewarding process. I discovered a future beyond the photograph in the human stories of photographer George Rodger and the boy he recorded in a landscape of horror, Sieg Maandag, a Jewish boy from Amsterdam, a victim and survivor of the Holocaust, his traumatic story a part of Jewish history, of Dutch history, and therefore of my history.

This work contains material that is the copyright property of others, which cannot be reproduced without the permission of the copyright owner. Such material is clearly identified in the text.

\section{ACKNOWLEDGEMENTS}

This article is dedicated to Sieg Maandag, Amsterdam, Netherlands, 1937-2013 and to George Rodger, Smarden, Great Britain, 1908-1995.

Many thanks to my tutors at Cambridge School of Art, Anglia Ruskin University, Cambridge: Véronique Chance, Edward Dimsdale and Kerstin Hacker; and to Kate Green, University of Nottingham, Nottingham.

Thanks to the cluster editors Clare Brant, James Metcalf, Jane Wildgoose.

Kind thanks to Keith Alcorn, Michael Atavar, Rommert Bakker, Martin Crawley and Jan Woolf for continued support and encouragement. 


\section{BIBLIOGRAPHY}

Atavar, Michael and Roelof Bakker. A-B. Unpublished draft, 2017.

Azoulay, Ariella. The Civil Contract of Photography. Mazali Rela and Danieli Ruvik (Trans.). New York: Zone Books, 2008.

Baer, Ulrich. Spectral Evidence: The Photography of Trauma. Cambridge Massachusetts and London, England: MIT Press, 2005.

Barthes, Roland. Camera Lucida: Reflections on Photography. R. Howard (Trans.). London: Vintage, 1993.

Barthes, Roland. Image Music Text. London: Fontana Press, 1977.

Benjamin, Andrew, Ed. Walter Benjamin and history. London: Bloomsbury Publishing PLC, 2005, https://ebookcentral.proquest.com/lib/anglia/detail.action?docID $=436233$. Date accessed: 1 August 2018.

Berger, John. About Looking. New York: Pantheon Books, 1980.

Brink, Cornelia. 'Secular Icons: Looking at Photographs from Nazi Concentration Camps.' In: History and Memory 20:1 (2000) 135-151.

'De film die nooit afkwam.' TV programme recording. EO, 4 May 2017 21:55. https://www. npostart.nl/2doc/04-05-2017/VPWON_1268665. Dates accessed: 12 July 2018 and 25 July 2018.

Green, Kate. 2014. George Rodger Archive Bergen-Belsen. [sound recording: interview with Jinx Rodger]. https://kategreen28.org/Bergen-Belsen. Date accessed: 11 June 2018.

Griffioen, Pim and Ron Zeller. Anne Frank website. 'The Netherlands: the greatest number of Jewish victims in Western Europe.' https://www.annefrank.org/en/anne-frank/goin-depth/netherlands-greatest-number-jewish-victims-western-europe/. Date accessed: 22 September 2019.

Happe, Katja. Veel Valse Hoop. De Jodenvervolging in 1940-1945 Nederland. Amsterdam/Antwerpen: Atlas Contact, 2018.

Hill, Paul and Thomas Cooper (eds.). Dialogue with Photography. Stockport: Dewi Lewis, 2005.

Hirsch, Marianne. The Generation of Postmemory: Writing and Visual Culture after the Holocaust. New York: Columbia University Press, 2012.

Hollandsche Schouwburg. https://jck.nl/en/location/national-holocaust-memorial. Date accessed: 16 May 2019.

Jaggi, Maya. 'The Last Word.' In: The Guardian, 21 December 2001. https://www.theguardian.com/education/2001/dec/21/artsandhumanities.highereducation. Date accessed: 23 April 2019.

Joods Monument. https://www.joodsmonument.nl. Date accessed: 12 May 2019.

Judt, Tony. Postwar: A History of Europe Since 1945. London: Pimlico, 2007.

Kok, Rene and Eric Somers. De Jodenvervolging in foto's. Nederland 1940-1945. Zwolle, Netherlands: W Books, 2019.

Life. 'Atrocities.' In: Life, 7 May 1945, 18:19. New York: Time \& Life, 1945.

Linfield, Susie. The Cruel Radiance: Photography and Political Violence. Chicago and London: The University of Chicago Press, 2010.

Luijters, Guus. In: Aline Pennewaard (ed.), 'In memoriam. De gedeporteerde en vermoorde Joodse, Roma en Sinti kinderen, 1942-1945.' Amsterdam, Netherlands: Nieuw Amsterdam, 2012.

Naggar, Carol. George Rodger: An Adventure in Photography, 1908-1995. New York: Syracuse University Press, 2003.

Nationaal Holocaust Museum. https://jck.nl/nl/tentoonstelling/de-jodenvervolging-fotos-nederland-1940-1945. Date accessed: 17 May 2019.

Nationaal Holocaust Museum, Amsterdam, 'De Jodenvervolging in foto's, Nederland 19401945.' Caption that accompanies the George Rodger photograph: 'Liberation. On 15 
April 1945 British forces liberated the concentration camp Bergen-Belsen. They were confronted with thousands of unburied corpses. The 7-year old Jewish Dutch boy Sieg Maandag received new clothes from the liberators. He survived the Holocaust.'

Pen, Hanneloes. 'Mensen moeten de originele foto van Sieg Maandag zien.' In: Het Parool, 4 May 2019. https://www.parool.nl/wereld/mensen-moeten-de-originele-foto-vansieg-maandag-zien b38d3200/?referer $=$ https\%3A\%2F\%2Fwww.google.com\%2F. Date accessed: 26 May 2019.

Prince, Erika and Gertjan Broek. Anne Frank House website. 'One day they simply weren't there anymore.' March 2015. www.annefrank.org/en/about-us/news-and-press/ news/2015/3/31/anne-franks-last-months. Date accessed: 6 June 2018.

Rodger, George. 50605938. 'Young boy dressed in shorts walks along a dirt road lined with the corpses of hundreds of prisoners who died at the Bergen-Belsen extermination camp, near the towns of Bergen and Celle, Germany, April 20, 1945.' The Life Picture Collection/ Getty Images, https://www.gettyimages.co.uk/license/50605938. Date accessed: 3 July 2018.

Rodger, George, Bruce Bernard and Peter Marlow. Humanity and Inhumanity: The Photographic Journey of George Rodger. London: Phaidon, 1999.

Sebald, W.G. The Rings of Saturn. London: Vintage, 2002.

Sollors, Werner. 'Malevolent Rectangles of Spectral Horror.' In: The Temptation of Despair. Cambridge, Massachusetts, US: The Bellknap Press of Harvard University Press, 2014.

Sontag, Susan. On Photography. London: Penguin, 2000.

Sontag, Susan. Regarding the Pain of Others. London: Penguin, 2003.

Stolpersteine. http://www.stolpersteine.eu/en/home/. Date accessed: 12 May 2019.

'De lijdensweg van een joods jongetje.' In: De Telegraaf, 18 March 1995.

United States Holocaust Memorial Museum. 'Holocaust Encyclopaedia: Bergen-Belsen,' https://encyclopedia.ushmm.org/content/en/article/Bergen-Belsen. Date accessed: 4 August 2018.

Van Berkel, Marcel. 'Holocaust representation in Dutch history textbooks 1960-2010.' In: Dossier 18:2 (2016). www.fupress.net/index.php/sf/article/download/18015/16811. Date accessed: 24 April 2019.

\section{ABOUT THE AUTHOR}

Roelof Bakker (Leeuwarden, Netherlands) has lived in the UK since 1984 and is based in Cambridge, where he graduated in 2019 with a Masters Degree in Fine Art at Cambridge School of Art. He is a photographer and the publisher of Negative Press London. His practice addresses the ever-increasing speed and momentum of contemporary life and the often tragic disposability of memory and the material. Negative Press publications include The Spots That Never Went (2018, Highly Commended Finalist of the 2019 Cornish Family Prize for Art and Design Publishing, presented by the National Gallery of Victoria, Australia), How Many Hopes Lie Buried Here Mother (2016), Strong Room (2014) with artist/writer Jane Wildgoose, and Still (2012), a collaboration with twenty-six international writers. Email: roelofbakker@mac.com,www.rbakker.com,www.neg-press.com. 


\section{REFERENCES}

1 Benjamin (ed.) 2005, Walter Benjamin and History (46).

2 Sebald 2002, The Rings of Saturn (60-61).

3 Baer 2005, Spectral Evidence: The Photography of Trauma $(8,9)$.

4 Linfield 2010, The Cruel Radiance: Photography and Political Violence (25).

5 Baer 2005 (9).

6 Sontag 2000, On Photography (19-20).

7 Jaggi 2001, 'The Last Word.' The Guardian.

8 Barthes 1993, Camera Lucida: Reflections on Photography (80).

9 Linfield 2010 (39).

10 Hirsch 2010, The Generation of Postmemory: Writing and Visual Culture after the Holocaust (5).

11 Naggar 2003, George Rodger: An Adventure in Photography, 1908-1995 (136).

12 Rodger, Bernard and Marlow 1999, Humanity and Inhumanity: The Photographic Journey of George Rodger (136-137).

13 Benjamin 1940 cited in Linfield 2010 (33).

14 Barthes 1993, Camera Lucida (42).

15 Idem (49).

16 Barthes 1993 (89).

17 Sontag 2003, Regarding the Pain of Others (80).

18 Brink 2000, 'Secular Icons: Looking at Photographs from Nazi Concentration Camps'. History and Memory (135-136).

19 Baer 2005 (115).

20 Idem (29).

21 Azoulay 2008. The Civil Contract of Photography (85).

22 Idem (14).

23 Ibidem.

24 Hirsch 2010 (142).

25 Sollors 2014, 'Malevolent Rectangles of Spectral Horror', The Temptation of Despair (68).

26 Idem (63).

27 Idem (64).

28 Judt 2007, Postwar: A History of Europe Since 1945 (202).

29 Barthes 1993 (84).

30 'De film die nooit afkwam' 2017.

31 Sollors 2014 (69).

32 Idem (76).

33 Telegraaf 1995, 'De lijdensweg van een joods jongetje' (page number not known).

34 Ibidem.

35 Telegraaf 1995 (page number not known).

36 Ibidem.

37 Naggar 2003 (138).

38 Barthes 1993 (47).

39 'De film die nooit afkwam' 2017.

40 Sollors 2014 (71).

41 Telegraaf 1995 (page number not known).

42 Azoulay 2008 (127).

43 Linfield 2010 (39).

44 Idem (118).

45 Idem (119).

46 Telegraaf 1995 (page number not known). 
47 Life 1945, 'Atrocities'. Life, 7 May 1945. 18:19 (32).

48 Idem (31).

49 Idem (32).

50 Idem (33).

51 'De film die nooit afkwam' 2017.

52 Sollors 2014 (67).

53 Life 1945 (32).

54 Sontag 2003 (57).

55 Sollors 2014 (66).

56 Judt 2007 (202).

57 Rodger. 50605938. 'Young boy dressed in shorts walks along a dirt road lined with the corpses of hundreds of prisoners who died at the Bergen-Belsen extermination camp, near the towns of Bergen and Celle, Germany, April 20, 1945.'

58 Linfield 2010 (82).

59 Baer 2005 (181).

60 Sebald, 2002 (62-63).

61 United States Holocaust Memorial Museum, Holocaust Encyclopedia: Bergen-Belsen.

62 Rodger 1945 cited in Naggar 2003 (138).

63 Sontag 2003 (23).

64 Hill and Cooper (eds) 2005, Dialogue with Photography (53).

65 Naggar 2003 (140).

66 'De film die nooit afkwam' 2017.

67 Linfield 2010 (73).

68 Idem (133).

69 Idem (73).

70 Ibidem.

71 Ibidem.

72 Hirschfeld 2018 cited in Happe 2018 (11).

73 Sollors 2014 (69).

74 Idem (69).

75 Idem (70).

76 Ibidem.

77 'De film die nooit afkwam' 2017.

78 Rahe 1995 cited in Sollors 2014 (74).

79 Nationaal Holocaust Museum.

80 Rahe 1995 cited in Sollors 2014 (74).

81 Sollors 2014 (70).

82 Idem (74).

83 Idem (70).

84 'De film die nooit afkwam' 2017.

85 Ibidem.

86 Rodger et al. 1999 (160).

87 Sollors 2014 (80).

88 Baer 2005 (182).

89 Barthes 1977, Image Music Text (25).

90 Rodger et al 1999 (136-137).

91 Life 1945 (32).

92 Sollors $2014(70)$.

93 Azoulay 2008 (107).

94 Rodger et al. 1999 (144-147).

95 Sontag 2003 (70). 
96 Telegraaf 1995.

97 Sollors 2014 (69).

98 Idem (68).

99 Nationaal Holocaust Museum.

100 Judt 2007 (202).

101 Rodger. 50605938.

102 Pen, Hanneloes. 'Mensen moeten de originele foto van Sieg Maandag zien.' Het Parool. 4 May 2014.

103 Ibidem.

104 Nationaal Holocaust Museum.

105 Kok and Somers 2019. De Jodenvervolging in foto's: Nederland 1940-1945 (273).

106 Van Berkel 2016. 'Holocaust representation in Dutch history textbooks 1960-2010' (47).

107 Telegraaf 1995.

108 Hollandsche Schouwburg.

109 The 104,000 figure also includes Jewish suicides in the Netherlands during the period from May 1940 to May 1945 and Jews who were killed or died while incarcerated by the Germans in the Netherlands, some of whom were buried in the Netherlands. (See also Griffioen and Zeller).

110 Nationaal Holocaust Museum, Amsterdam, 'De Jodenvervolging in foto's, Nederland 1940-1945'. Caption that accompanies the George Rodger photograph: 'Liberation. On 15 April 1945 British forces liberated the concentration camp Bergen-Belsen. They were confronted with thousands of unburied corpses. The 7-year old Jewish Dutch boy Sieg Maandag received new clothes from the liberators. He survived the Holocaust.'

111 Happe 2018, Veel Valse Hoop. De Jodenvervolging in 1940-1945 Nederland.

112 Azoulay 2008 (60).

113 Baer 2005 (182).

114 Linfield 2010 (33). 